\title{
Relationship between Green Supply Chain Adoption and Supplier Innovation Initiative: Evidence from Manufacturing Firms in Accra Metropolis
}

\author{
Bruce Emmanuel ${ }^{1 *}$, Yegenmuradov Mammet ${ }^{1}$, Armel Kaze ${ }^{2}$, Owusu Ansah Priscilla ${ }^{3}$, \\ Akyen Bentum Alfred ${ }^{4}$
}

\begin{abstract}
${ }^{1}$ School of Management and Economics, University of Electronic Science and Technology of China, Chengdu, China ${ }^{2}$ Center for African Studies, School of International Relations, Yunnan University, Kunming, China ${ }^{3}$ Center for West African Studies, University of Electronic Science and Technology of China, Chengdu, China ${ }^{4}$ Institute of Distance Learning, Kwame Nkrumah University of Science and Technology, Kumasi, Ghana Email: ^kinbuki100@outlook.com
\end{abstract}

How to cite this paper: Emmanuel, B., Mammet, Y., Kaze, A., Priscilla, O. A., Alfred, A. B. (2021). Relationship between Green Supply Chain Adoption and Supplier Innovation Initiative: Evidence from Manufacturing Firms in Accra Metropolis. Open Journal of Business and Management, 9, 2780-2792.

https://doi.org/10.4236/ojbm.2021.96155

Received: April 2, 2021

Accepted: November 2, 2021

Published: November 5, 2021

Copyright $\odot 2021$ by author(s) and Scientific Research Publishing Inc. This work is licensed under the Creative Commons Attribution International License (CC BY 4.0).

http://creativecommons.org/licenses/by/4.0/

\begin{abstract}
The relationship between the supplier innovation initiative and the green supply chain adoption has received a great deal of interest from business managers across the world. The study sought to examine the relationship between green supply chain adoption, supplier innovation initiative, and performance of manufacturing firms in the Accra Metropolis. Methodology: The study employed a quantitative approach by adopting an exploratory research design. A structured questionnaire was used to collect data from 20 pre-qualified manufacturing firms in the Accra Metropolis using purposive and simple random sampling techniques. Multiple linear regression techniques were used to examine the relationship between green supply chain adoption, supplier innovation initiative, and manufacturing firms' performance in the Accra Metropolis. Results: The study found that innovation initiatives and drivers of the green supply chain (external influences) have statistically significant positive effects on the green supply chain management adoption. Also, it was found that green supply chain management adoption has a statistically significant positive impact on the performance of the manufacturing firms in the Accra Metropolis. Conclusion: We recommend that manufacturing firms in Accra Metropolis should continue to introduce a mix of green practices and green innovation initiatives to achieve GSCM. This is crucial to affirm the accomplishment of environmental, economic, and social gains and improved performance in the supply chain. Future studies should introduce a moderating variable such as information technology to ascertain how it inte-
\end{abstract}


racts with the other variables in the study.

\section{Keywords}

Supplier Innovation, Green Supply Chain, Innovation Initiative, Sustainable Supply Chain Management

\section{Introduction}

Globally, green concerns have been a challenge for individuals as well as companies to balance environmental friendliness with profit-making. Many researchers, including (Seuring \& Müller, 2008; Koller et al., 2011; Irum et al., 2018) argued that businesses, especially manufacturing firms, are the major contributors to environmental decay. Due to the extreme environmental impacts of manufacturing processes that often contribute to the degradation of the ozone layer, global producers were warned about balancing green supply chain practices and supplier creativity to foster sustainable economic growth (Guang Shi et al., 2012; Zhu, Sarkis, \& Lai, 2019).

Green Supply Chain Practices (GSCP) have been defined in many ways by researchers to be a viable green supply chain management strategy covering the manufacturing practices of companies, the impact of those activities, and how to reduce the impact on the natural environment while generating a profit (Guang Shi et al., 2012). Srivastava (2007) defined green supply chain practices as sets of actions and programmes conducted by a company to reduce its adverse environmental impacts. Guang Shi et al. (2012) believe that credible GSCP would be one of the best ways for suppliers to respond to intra- and inter-consolidated management concerns and to raise global environmental consciousness. A consistent practice of GSCP will improve financial performance in many economies in their attempts to grow green supply chain adoption and supplier innovation initiatives (Seuring \& Müller, 2008; Koller et al., 2011), reduce emissions, improve market share and sustainability as a means of sustainable growth (Hsu et al., 2013). While there are varying definitions of GSCP, in essence, GSCP can be considered as incorporating sustainability thinking into supply chain management. This includes the design, procurement, and selection of products, the manufacturing processes, the distribution by buyers of the finished product, and the product's maintenance throughout its useful life.

In modern trends, it is believed that GSCP are an essential significant factor for manufacturing companies and helps in contributing to environmental friendliness in the manufacturing process, supply chain, environmental footprint, and recycling industries should be a core approach adopted by these businesses. Instead of merely responding to specific accidents or evolving environmental regulations, businesses can foresee or avoid environmental challenges by amending policies (Aragón-Correa et al., 2008; Horbach \& Rammer, 2020). However, Abdel-Baset et al. (2019) stated that every organization needs a green supply chain, 
but greening should be a concerted initiative between managers, companies, greens advocates, and governments worldwide.

To mitigate the adverse consequences of environmental results, several firms, including manufacturers in developed and least developed countries, have implemented green solutions, practicing green supply chain and supplier innovation in their industries to enhance market efficiency. Latest studies indicate that environmental problems have been relevant and important for firms to set up and run (AlGhwayeen \& Abdallah, 2018; Dawei et al., 2015; Abeyratne \& Monfared, 2016). Many environmental researchers conclude that all businesses, regardless of scale, sector or country, have considered green considerations (Dash Wu et al., 2019; Vachon, 2007; Vachon \& Klassen, 2008).

However, empirical evidence indicates that manufacturing companies are the most restricted in adopting green supply chain activities. This suggests that the development of a green supply chain is vital to manufacturing companies' sustainability (Stevenson \& Spring, 2007). The investigation of this topic is especially important for developing countries. Many of the studies on the relationship between green policies and performance have concentrated on developed countries; but there were also studies in the mining industry, waste disposal firms, etc (Seuring \& Müller, 2008; Koller et al., 2011). It is against this backdrop that this study seeks to explore the relationship between green supply chain adoption and innovation orientation of manufacturing firms in Ghana.

Besides, studies reviewed revealed that no study in Ghana investigated the relationships between the external influence of green supply chain innovation and green supply chain adoption and how they ultimately impact the performance of the manufacturing firms in Accra Metropolis. Therefore, the current study sought to close the research gap by examining the relationship between external influence, innovation orientation, and green supply chain adoption.

\section{Research Methodology}

\section{Data Collection Procedure}

This research includes primary and secondary data to assess the relationship in the study. To achieve the research objectives, the study used a structured questionnaire built-in line with the study's objectives to collect data primary data from the manufacturing companies' respondents within Accra Metropolis. The questionnaire was built based on the literature reviewed for the study. The questionnaires segmented into four parts; Section A of the questionnaire contains demographic variables such as annual income, number of workers, etc., type of organization, and so on. Section B covers questions measuring supplier innovation initiatives. Section $\mathrm{C}$ contains questions measuring green supply chain adoption. Section D contained equations measuring the performance of manufacturing firms. To ensure that the respondents were clear on the questions, content validity was accomplished by a pre-testing exercise using 10 respondents from 10 manufacturing 
firms before the actual data collection. Responding to the questions, they called for some clarifications that might further explain the key survey questions.

Moreover, the questionnaires administered directly to the respondents were used to allow the researcher to explain the questionnaire to the respondents who may not understand the questionnaire clearly. This also led to the high rate of retrieval of questionnaires from respondents. The online platforms used to administer the questionnaires were used to get in touch with firms whose managers and respondents were not readily accessible.

For the evaluation exercise, the study selected lists of manufacturing firms in Accra, Ghana. The study used an explanatory research design to collect information on the relationship between innovation orientation and green supply chain adoption and performance of selected manufacturing firms in Accra Metropolis (Creswell \& Creswell, 2017). This research design is selected because it helps assess the essence of the problem and helps the researcher gain a deeper understanding of the problem.

Furthermore, the registered manufacturing firms operating within the Accra Metropolis constitute the population of the study. The manufacturing companies' selection was based on the adoption by the Green Supply Chain Management (GSCM). Those identified to participate in the GSCM practices were chosen. The purposive sampling and simple random sampling methods were used to pick the manufacturing companies to engage in the study (Kumar, 2019). This sampling methodology was introduced as the organizations that practice GSCM is the best place to determine problems relevant to environmentally-conscious practices. This constitutes the sampling frame of the study. Also, the Simple Random Sampling Method was used to choose the organizations for the sample. Simple random sampling is a sampling method in which each object in the population has the same chance and probability of being included in the study. In this case, companies' preference depends solely on chance or chance (Mugenda \& Mugenda, 2003; Antoni et al., 2019). The analysis then randomly sampled 100 pre-qualified manufacturing companies operating in Accra Metropolis. This strategy was used to pick organizations to give all qualified firms in the Accra Metropolis to engage in the research. Formal permission was obtained from the manufacturing firms' management/owners to research within their organizations. The objectives of the research were clarified to each study subject and decided to participate. For the analysis of the study, data collected has been revised to check for inconsistencies in the responses provided by the respondents. The data was then encoded in Statistic Product and Service Solutions (SPSS) version 22 for analysis. Descriptive methods will be used for the development of tables and frequencies. The interaction between independent variables (competitors' pressure, government pressure, consumer pressure, supplier pressure, and innovation orientation) and manufacturing companies' performance as dependent variables. In total, 100 questionnaires were handled of which 83 were obtained.

However, multiple regressions were used. 
The general model is stated as follows:

However, multiple regressions were used.

The general model is stated as follows:

$$
\gamma=\alpha+\beta_{1} X_{1}+\beta_{2} X_{2}+\beta_{3} X_{3} \cdots \beta_{k} \beta_{k}+\varepsilon
$$

The specified regression model is

$$
\begin{gathered}
\text { GSCA }=\alpha+\beta_{1} \text { EIGI }+\beta_{2} \mathrm{INO}+\varepsilon \\
\mathrm{PMO}=\alpha+\beta_{1} \mathrm{SCMAD}+\varepsilon
\end{gathered}
$$

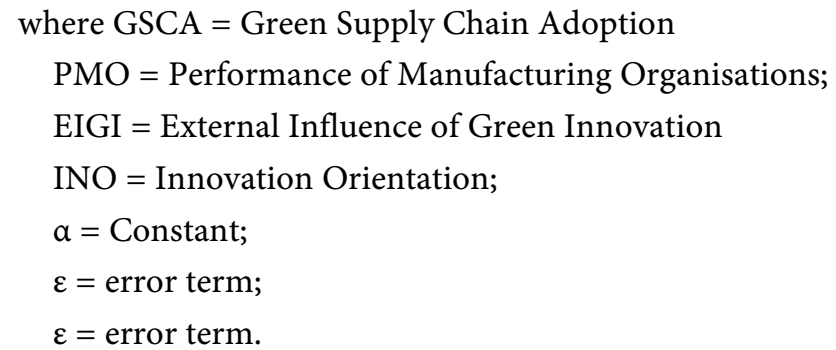

\section{Results}

The results of the demographic data analysis revealed that most of the manufacturing firms in Accra Metropolis medium-sized, representing 47.0\% of the total respondents. This is followed by large firms forming $31.3 \%$ and small firms constituting $21.7 \%$ of the respondents. The manufacturing firms were registered as a sole proprietorship, limited liability company, and partnerships. The highest proportion of the firms is sole proprietorship businesses (53\%), followed by partnership businesses (31.3\%). Only $10.8 \%$ of the firms are registered as limited liability companies. In addition, males constituting $54.2 \%$, were the highest respondents compared to $45.8 \%$ females. This finding points out that males dominated the manufacturing industry in the Accra Metropolis. Further, the analysis outcome revealed that most of the firms that took part in the study were in operation between 1 - 5 years (42.2\%). Firms operating for over 10 years formed $21.7 \%$, and businesses that are less than 1 year represented $19.3 \%$. The result also showed that firms in the age bracket of $6-10$ years constitute $16.9 \%$ of the manufacturing firm respondents. In relation to the respondents' educational background, the analysis revealed that most of the undergraduate degree holders $(62.7 \%)$ and $19.3 \%$ of them hold a diploma. The rest $18.1 \%$ hold a master's degree, meaning all the respondents have formal education and can read appreciate the subject matter of the study (Table 1).

As evident from Table 2, the external influence of green innovation was analyzed using mean, standard deviation, and ranking. In assessing the external influence of green innovation, five (5) variables were tested using seven points Likert Scale. As depicted in Table 3, the respondents agreed to drivers of green innovation in their firms. The respondents showed that the consumer's pressure inspires our business to adopt green technology while producing a product with a mean value of 6.83. It has also been found that CSO/Media's environmental 
Table 1. Provides descriptive statistics (demographic information) of the manufacturing firms and respondents.

\begin{tabular}{|c|c|c|c|}
\hline & & Frequency & Percent \\
\hline \multirow{3}{*}{ Business Size } & Small & 18 & 21.7 \\
\hline & Medium & 39 & 47.0 \\
\hline & Large & 26 & 31.3 \\
\hline \multirow{3}{*}{ Form of Business } & Sole Proprietorship & 44 & 53.0 \\
\hline & Limited Liability Company & 9 & 10.8 \\
\hline & Partnership & 30 & 36.1 \\
\hline \multirow{2}{*}{ Gender } & Male & 45 & 54.2 \\
\hline & Female & 38 & 45.8 \\
\hline \multirow{4}{*}{ Age of Business } & Less than 1 year & 16 & 19.3 \\
\hline & $1-5$ years & 35 & 42.2 \\
\hline & $6-10$ years & 14 & 16.9 \\
\hline & Over 10 years & 18 & 21.7 \\
\hline \multirow{3}{*}{ Educational Level } & Diploma & 16 & 19.3 \\
\hline & Undergraduate Degree & 52 & 62.7 \\
\hline & Master's degree & 15 & 18.1 \\
\hline $\mathrm{N}=83$ & & & \\
\hline
\end{tabular}

Source: Field data (2020).

Table 2. External influence of green innovation.

Variable

Government laws on environmental protection activities that are stringent and robust and government policy strengthen our corporations' move towards green innovation

Our business's drive towards green innovation is motivated by our rivals introducing new environmental standards that give advantages.

Customer pressure drives our organization to embrace renewable technology when making a commodity.

Our supplier's refusal to provide resources or provide facilities that are perceived to affect the environment drives our company's gree innovation.

Environmental pressure CSO/Media drives the green creativity of our business

Mean Std. Dev.

Source: Field data (2020). 
Table 3. Innovation orientation.

\begin{tabular}{|c|c|c|}
\hline Variable & Mean & Std Dev. \\
\hline $\begin{array}{l}\text { Our organisation is introducing new technologies that encourage } \\
\text { environmentally sustainable development }\end{array}$ & 5.57 & 1.262 \\
\hline $\begin{array}{l}\text { Our organisation builds the expertise of staff to inspire them to be } \\
\text { green innovation-oriented in their company operations. }\end{array}$ & 6.14 & 0.783 \\
\hline $\begin{array}{l}\text { Our organisation engages in value creation strategies such as market } \\
\text { segmentation, introducing innovative goods for new markets that are } \\
\text { environmentally friendly. }\end{array}$ & 5.60 & 1.439 \\
\hline Our business is involved in a green product or service customization & 5.67 & 1.190 \\
\hline Our company uses green engineering in the manufacture of goods & 5.61 & 1.314 \\
\hline
\end{tabular}

Source: Field data (2020).

demand pushes green innovation (mean $=6.11$ ), government laws on environmental management activities are stringent and rigorous. Government policies improve the push of their companies towards green innovation (mean $=5.88$ ) and the reluctance of vendors to supply resources or provide services that are perceived to be detrimental to the environment. The outcome also showed that the company's push for green engineering had been affected by our rivals introducing new environmental regulations that provide some form of advantage $($ mean $=5.71)$. The results imply that many external influences drive manufacturing firms to go towards green innovation in their production activities. Alvarez-Milán et al. (2018) government regulations on a change in environmental practices giving the greatest pressure to businesses as the government can take the role of both a regulator and the consumer. In addition, companies' drive to ensure their global visibility has also been established to depend on companies' compliance to local and global regulation hence a bad report from the state can hamper a company's drive to seek international recognition.

Next part of the analysis dwells on the descriptive statistics of innovation orientation.

With the innovation orientation, the result has shown that the organization develops staff skills to enable them to be green innovation-oriented in its operations in the company (mean $=6.14$ ). It was also noticed that the organization is engaged in green product or service customization (mean $=5.67$ ). As a result, Accra Metropolis companies are undergoing an innovation orientation. Innovation is essentially a preparation for an enterprise to implement emerging innovations, tools, skills, ideas, and knowledge systems integrated into a company's learning process. The result also shows that the organization uses green manufacturing in the manufacture of products (mean $=5.61$ ), the company engages in value generation initiatives such as market segmentation, the introduction of innovative products for new markets that are environmentally friendly (mean = 5.60) and the company adopts new technology that encourages environmentally friendly production (mean $=5.57$ ).

The descriptive statistics of green supply chain adoption is depicted in Table 
4.

Per Table 4, the supply chain adoption was assessed from monitoring-based GSCM and support-based GSCM. The results showed that manufacturing firms obtain and process information from vendors (mean $=5.53$ ). The company lays out the supplier assessment requirements for its suppliers (mean $=6.18$ ), and the company reviews the environmental performance of the incoming products and those who supply the goods (mean $=5.88$ ). De Giovanni and Vinzi (2012) stated that GSCM monitoring is usually associated with output controls with clear performance requirements. This includes collecting and analyzing information from providers, the development of standards for supplier reviews, and the evaluation of the environmental efficiency of incoming products and suppliers that provide those goods.

Concerning the support-based GSCM approach to green supply chain implementation, firms offer training and training services to suppliers (mean $=6.49$ ), firms sponsor environmental summits for suppliers to facilitate knowledge and expertise trading (mean $=5.93$ ) and firms are defined to conduct cooperative technical research with suppliers to develop new technology (mean $=5.92$ ).

In addition, the estimation results for the manufacturing firms' performance over five years, are shown in Table 5. The outcomes showed that the firms had performed creditably over the period. The sales volume of the forms has increased, the profit has increased, and the firm's customers are satisfied with the firms' products and services. The results further indicated that the business's free cash flow had improved; the firms' market value-added has seen an improvement, and return on investment has increased. Based on the adopted measurement for the firm performance over the five years under review, the firms have improved their performance.

Table 4. Green supply chain adoption.

\begin{tabular}{|c|c|c|}
\hline Variable & Mean & Std Dev. \\
\hline \multicolumn{3}{|l|}{ Monitoring in green supply chain management } \\
\hline $\begin{array}{l}\text { Our company undertakes to obtain and process information from } \\
\text { manufacturers }\end{array}$ & 5.53 & 1.231 \\
\hline $\begin{array}{l}\text { Our organization has set the supplier evaluation requirements for our } \\
\text { suppliers }\end{array}$ & $r_{6.18}$ & 0.899 \\
\hline $\begin{array}{l}\text { Our organization analyses the environmental efficiency of the } \\
\text { incoming products and the suppliers who supply those goods. }\end{array}$ & 5.88 & 1.214 \\
\hline \multicolumn{3}{|l|}{ Green supply chain management based on funding } \\
\hline Our business offers to consult and to train services to vendors. & 6.49 & 0.632 \\
\hline $\begin{array}{l}\text { Our organization sponsors sustainability summits for suppliers to } \\
\text { encourage knowledge and knowledge trading. }\end{array}$ & 5.93 & 1.276 \\
\hline $\begin{array}{l}\text { Our business undertakes joint applied collaboration with } \\
\text { manufacturers to discover different products or methods. }\end{array}$ & 5.92 & 0.858 \\
\hline
\end{tabular}

Source: Field data (2020). 
Table 5. Performance of Manufacturing Firms.

\begin{tabular}{ccc}
\hline Variable & Mean & Std. Dev. \\
\hline The volume of revenue has grown. & 5.81 & 1.505 \\
There has been a rise in benefit & 6.06 & 1.162 \\
Customers are pleased with our products/services & 5.76 & 1.340 \\
The free cash flow has improved. & 5.86 & 1.432 \\
Improvement of consumer value-added to the company's product & 5.60 & 1.456 \\
The return on investment has improved & 5.95 & 1.103 \\
\hline
\end{tabular}

Source: Field data (2020).

\section{Discussion}

Table 6 contains the pooled regression results of the relationship between green supply chain adoption, innovation orientation, and manufacturing firms' performance in the Accra Metropolis using multiple linear regression.

The model's OLS results establish the relationship between supply chain adoption, external influence, and innovation orientation. The variables are statistically significant and exhibit $98.8 \%$ for R-Squared, $98.8 \%$ for adjusted RSquared, and F-probability (0.000). This indicates that the variables in the model explain $98 \%$ of the variations in the dependent variable. However, these results suggest that other variables could be added to explain the variability in the firms' supply chain adoption indicators but to focus on the study's objectives, the study relies on the variables above for decision making. The researcher suppressed the constant term to distribute the effect on the regressors.

\section{Innovation Orientation and Performance of Manufacturing Firms}

The result showed that innovation orientation has a statistically significant favorable influence on green supply chain adoption. Thus, a unit increase in innovation orientation could cause an $11.7 \%$ point increase in green supply chain adoption. The finding implies that when the firms are engaged in innovative ways of doing things, they can improve the green supply chain adoption. Moreover, the coefficient of green supply chain innovation's external influence has a statistically significant positive relationship with green supply chain adoption. The result suggests that a percentage increase in green innovation's external influence could cause an $87.4 \%$ percentage point increase in the supply chain management adoption. This explains that firms that pay particular attention to the external influence of green innovation are likely to be involved in supply chain adoption in their respective industries. The pressures from the government, competitors, influential suppliers could encourage manufacturing firms to adopt green supply chain management practices.

The relationship between green supply chain adoption and the performance of manufacturing firms in the Accra Metropolis is discussed in Table 7. 
Table 6. Regression results (Dependent Variable): Green Supply Chain Adoption.

\begin{tabular}{ccccc}
\hline Variable & Coefficient & Standard Error & t-value & P-value \\
\hline Innovation Orientation & 0.117 & 0.061 & 1.920 & $0.059^{\star}$ \\
Green Supply Chain Adoption & 0.874 & 0.049 & 17.940 & $0.000^{\star *}$ \\
R-Squared & & & 0.988 \\
Adj. R-Squared & & & 0.988 \\
F-Probability & & & 0.000 \\
\hline
\end{tabular}

Source: Field data (2020). ${ }^{\star} 5 \%$ significance level; ${ }^{\star} 10 \%$ significance level.

Table 7. Regression results (Dependent Variable: Firm Performance).

\begin{tabular}{ccccc}
\hline Variable & Coefficient & Standard Error & t-value & P-value \\
\hline Green Supply Chain Adoption & 0.992 & 0.022 & 45.96 & 0.000 \\
R-Squared & & & 0.963 \\
Adj. R-Squared & & & 0.962 \\
F-Probability & & & 0.000 \\
\hline
\end{tabular}

Source: Field data (2020).

Table 7 shows the model's OLS results of the specified to establish the relationship between the firms' green supply chain adoption and performance. The variables are statistically significant and exhibit $96.3 \%$ for R-Squared, $96.2 \%$ for adjusted R-Squared, and F-probability (0.000). This means that the independent variable in the model explains $96 \%$ of the dependent variable variations. The result showed a statistically significant positive relationship between the green supply chain adoption and the manufacturing firms' performance. The results state that, when green supply chain adoption increased by one percentage point, the performance of the firms increases by $99.2 \%$ points. This signifies that when manufacturing firms adopt green supply chain management practices, it translates into improved company performance.

\section{Conclusion and Future Directions for Research}

The study examined the relationship between green supply chain adoption, supplier innovation initiative, and performance of manufacturing firms in the Accra Metropolis. Furthermore, from a theoretical point of view, the literature revision, therefore, introduced theories: altruism and theory of collectivism stewardship and applied in the analysis. Several findings are noted as follows. Firstly, the study showed that customer pressure drives our business to embrace green technology while making a product. The study found that environmental demand from CSO/Media drives green innovation by the company, that government laws on environmental protection activities are stringent and rigorous, and that government policies enhance their firms' push for green innovation, and that the reluctance of suppliers to supply resources or to provide facilities that are thought 
to hurt the environment, drives green innovation by the company. Secondly, the findings showed that our competitor's push for green innovation had been motivated by introducing new environmental regulations that provide some advantages. The external influence has a statistically significant positive relationship with the green supply chain adoption. The result suggests that a percentage increase in green innovation's external influence could cause green supply chain adoption to increase. This explains that firms that pay particular attention to green innovation drivers are likely to be involved in supply chain management adoption in their respective industries. Thirdly, the result from our study demonstrated that the companies develop staff expertise to enable them to be green innovation-oriented in their operations in the company. It was also noticed that the organization is involved in green product or service customization. The result also shows that the company uses green innovation in the manufacture of products. The firms engage in value generation techniques such as market segmentation and innovative products for new and environmentally sustainable markets. The regression result showed that innovation orientation has a statistically significant positive influence on green supply chain adoption. The finding implies that when the firms are engaged in innovative ways of doing things, they can improve green supply chain adoption.

Furthermore, the analysis showed that manufacturing companies conduct to obtain and store information from vendors. The company lays out the supplier assessment requirements for its suppliers, and the company reviews the environmental efficiency of the incoming products and the suppliers who supply those goods. Firms offer training and training services to suppliers. The regression result showed a statistically significant positive relationship between the green supply chain adoption and the manufacturing firms' performance. Thus, a unit increase in green supply chain adoption could cause the performance of firms to increase. Finally, the study found a significant positive relationship with green supply chain adoption. This implies that firms that pay particular attention to the external influence of green innovation are likely to be involved in supply chain management adoption in their respective industries. It is also concluded that innovation orientation has a statistically significant positive influence on green supply chain adoption. The finding indicates that when the firms are engaged in innovative ways of doing things, there is the possibility of the firms improving the green supply chain adoption. The study further concluded that there is a statistically significant positive relationship between green supply chain adoption and the manufacturing firms' performance.

Compared with previous studies, this paper has some limitations. The study, however, only concentrated on a small sample of manufacturing firms in Ghana. The focus on these firms leaves out other Ghanaian firms (industries) that may equally be beneficial to the current study. Therefore, the results may not have strong external validity. The restriction to manufacturing firms in the Accra Metropolis is due to time constraints in conducting the study. Further, this study 
did not attempt to control for other sources of organizational performance. However, future research could extend the observations on introducing a moderating variable such as information technology to ascertain how it interacts with the other variables in the study. The study should be conducted in all the regions of Ghana.

\section{Conflicts of Interest}

The authors declare no conflicts of interest regarding the publication of this paper.

\section{References}

Abeyratne, S. A., \& Monfared, R. P. (2016). Blockchain Ready Manufacturing Supply Chain Using Distributed Ledger. International Journal of Research in Engineering Technology in Society, 5, $10 \mathrm{p}$.

Abdel-Baset, M., Chang, V., \& Gamal, A. (2019). Evaluation of the Green Supply Chain Management Practices: A Novel Neutrosophic Approach. Computers in Industry, 108, 210-220. https://doi.org/10.1016/j.compind.2019.02.013

Al-Ghwayeen, W. S., \& Abdallah, A. B. (2018). Green Supply Chain Management and Export Performance: The Mediating Role of Environmental Performance. Journal of Manufacturing Technology Management, 29, 1233-1252.

https://doi.org/10.1108/jmtm-03-2018-0079

Alvarez-Milán, A., Felix, R., Rauschnabel, P. A., \& Hinsch, C. (2018). Strategic Customer Engagement Marketing: A Decision-Making Framework. Journal of Business Research, 92, 61-70. https://doi.org/10.1016/j.jbusres.2018.07.017

Antoni, J., \& Borghesani, P. (2019). A Statistical Methodology for the Design of Condition Indicators. Mechanical Systems and Signal Processing, 114, 290-327. https://doi.org/10.1016/j.ymssp.2018.05.012

Aragón-Correa, J. A., Hurtado-Torres, N., Sharma, S., \& García-Morales, V. J. (2008). Environmental Strategy and Performance in Small Firms: A Resource-Based Perspective. Journal of Environmental Management, 86, 88-103.

https://doi.org/10.1016/j.jenvman.2006.11.022

Creswell, J. W., \& Creswell, J. D. (2017). Research Design: Qualitative, Quantitative, and Mixed Methods Approaches (Vol. 55). Sage Publications.

Dash Wu, D., Yang, L., \& Olson, D. L. (2019). Green Supply Chain Management under Capital Constraint. International Journal of Production Economics, 215, 3-10. https://doi.org/10.1016/j.ijpe.2018.09.016

Dawei, Z., Hamid, A. B. A., Chin, T. A., \& Leng, K. C. (2015). Green Supply Chain Management: A Literature Review. Sains Humanika, 5, 15-21.

De Giovanni, P., \& Vinzi, V. E. (2012). Covariance versus Component-Based Estimations of Performance in Green Supply Chain Management. International Journal of Production Economics, 135, 907-916. https://doi.org/10.1016/j.ijpe.2011.11.001

Guang Shi, V., Lenny Koh, S., Baldwin, J., \& Cucchiella, F. (2012). Natural Resource Based Green Supply Chain Management. Supply Chain Management, 17, 54-67. https://doi.org/10.1108/13598541211212203

Horbach, J., \& Rammer, C. (2020). Circular Economy Innovations, Growth and Employment at the Firm Level: Empirical Evidence from Germany. Journal of Industrial 
Ecology, 24, 615-625. https://doi.org/10.1111/jiec.12977

Hsu, C.-W., Kuo, T.-C., Chen, S.-H., \& Hu, A. H. (2013). Using DEMATEL to Develop a Carbon Management Model of Supplier Selection in Green Supply Chain Management. Journal of Cleaner Production, 56, 164-172. https://doi.org/10.1016/j.jclepro.2011.09.012

Irum, S., Qureshi, M. I., Ashfaq, M., Sami, A., Bhatti, M. N., \& Umar, A. (2018). A Review of Green Supply Chain Management Practices in Asian Countries. International Journal of Engineering \& Technology, 7, 1094-1096. https://doi.org/10.14419/ijet.v7i2.29.14319

Koller, M., Floh, A., \& Zauner, A. (2011). Further Insights into Perceived Value and Consumer Loyalty: A “Green” Perspective. Psychology \& Marketing, 28, 1154-1176. https://doi.org/10.1002/mar.20432

Kumar, R. (2019). Research Methodology: A Step-by-Step Guide for Beginners (Vol. 4). Sage Publications Limited.

Mugenda, O. M., \& Mugenda, A. G. (2003). Research Methods, Quantitative and Qualitative Approaches. ACT, Nairobi.

Seuring, S., \& Müller, M. (2008). From a Literature Review to a Conceptual Framework for Sustainable Supply Chain Management. Journal of Cleaner Production, 16, 16991710. https://doi.org/10.1016/j.jclepro.2008.04.020

Srivastava, S. K. (2007). Green Supply-Chain Management: A State-of-the-Art Literature Review. International Journal of Management Reviews, 9, 53-80. https://doi.org/10.1111/j.1468-2370.2007.00202.x

Stevenson, M., \& Spring, M. (2007). Flexibility from a Supply Chain Perspective: Definition and Review. International Journal of Operations \& Production Management, 27, 685-713. https://doi.org/10.1108/01443570710756956

Vachon, S. (2007). Green Supply Chain Practices and the Selection of Environmental Technologies. International Journal of Production Research, 45, 4357-4379. https://doi.org/10.1080/00207540701440303

Vachon, S., \& Klassen, R. D. (2008). Environmental Management and Manufacturing Performance: The Role of Collaboration in the Supply Chain. International Journal of Production Economics, 111, 299-315. https://doi.org/10.1016/j.ijpe.2006.11.030

Zhu, Q. H., Sarkis, J., \& Lai, K. H. (2019). Choosing the Right Approach to Green Your Supply Chains. Modern Supply Chain Research Applications, 1, 54-67. https://doi.org/10.1108/mscra-02-2019-0006 